\title{
GIS Based Mapping of Soil Fertility Status of Tehsil Jobat, District Alirajpur, Madhya Pradesh, India
}

\author{
Deepak Kumar Ausari ${ }^{1}$, Bharat Singh $^{1}$ and Aakash ${ }^{2 *}$, \\ Rahul Kumawat ${ }^{1}$ and Yashwant Gehlot ${ }^{1}$
}

\author{
${ }^{1}$ Department of Soil Science and Agricultural Chemistry, ${ }^{2}$ Department of Agronomy, \\ RVSKVV, College of Agriculture, Indore-452001, India \\ ${ }^{3}$ Department of Soil Science and Agricultural Chemistry, RVSKVV, \\ College of Agriculture, Sehore-466001, India \\ *Corresponding author
}

\section{A B S T R A C T}

\begin{tabular}{l} 
K e y w o r d s \\
$\begin{array}{l}\text { Arc-GIS, Electrical } \\
\text { conductivity, } \\
\text { Organic carbon, } \\
\text { Site-specific } \\
\text { nutrient } \\
\text { management, Soil } \\
\text { reaction }\end{array}$ \\
Article Info \\
$\begin{array}{l}\text { Accepted: } \\
\text { 04 September } 2020 \\
\text { Available Online: } \\
10 \text { October } 2020\end{array}$ \\
\hline
\end{tabular}

Introduction

Soil is the basic requirement of all life on earth. The origin of life has been attributed is soil along with other basic elements. Soil the source of life is passionate. An excessive or imbalanced application of fertilizers not only wastes this limited costly resources, but also pollutes the environment. In the face of economic and environmental concerns, farmers face in increasing challenge of
The investigation was conducted in 2018-19 at Jobat Tehsil, District Alirajpur, to know the soil reaction, electrical conductivity, organic carbon content and status of primary nutrients. Surface soil samples were collected grid wise by using cadastral map of the study area and were analyzed for their fertility status. The value of $\mathrm{pH}$, electrical conductivity, and organic carbon was ranged 6.15 to 8.48 , 0.08 to $0.74 \mathrm{dSm}^{-1}$, and 0.20 to $0.81 \%$ respectively. The available nitrogen, phosphorus, potassium ranged from 96 to $315 \mathrm{~kg} \mathrm{ha}^{-1}, 0.60$ to $25.20 \mathrm{~kg} \mathrm{ha}^{-1}$ and 114.46 to $472.64 \mathrm{~kg} \mathrm{ha}^{-1}$ respectively. The available nitrogen was in low, phosphorus content varied from low to medium and medium to high in potassium. Using the field survey and laboratory analysis results, the soil heterogeneity units were determined using Arc-GIS 10.5.1. Based on data obtained after analysis; the maps of all parameters were prepared which will be successfully used in the future for site-specific nutrient management. 
This assessment includes a number of processes using field and laboratory diagnostics and a number of mathematical models that link the relationship between soil nutrient level and plant responsiveness. It is necessary to know the proper way to evaluate the soil fertility status and to identify the nutrient deficiency (Pawar et al., 2020). There are various techniques for soil fertility evaluation, among them soil testing is an indispensible tool in soil fertility management for sustained soil productivity (Havlin et al., 2010). Soil analysis is helpful for better understanding of the soils to increase the crop production and obtaining sustainable yield.

Soil available nutrients status of an area using Global Positioning System (GPS) will help in formulating site-specific balanced fertilizer recommendation and to understand the status of soil fertility spatially and temporally. Under this context, prepare a fertility map and of such map as a decision support tool for nutrient management, will not only be helpful for adopting a rational approach compared to farmer practices or blanket use of state recommended fertilization, but will also reduce the necessity for elaborate plot-by-plot soil testing activities. Geographic information system (GIS) is a powerful tool, which helps to integrate many types of spatial information such as agroclimatic zone, land use, soil management, etc. to derive useful information (Singh et al., 2017) Furthermore, GIS generated soil fertility maps may serve as a decision support tool for nutrient management.

\section{Materials and Methods}

\section{Description of study area}

Alirajpur district of Madhya Pradesh, is situated $22^{\circ} 18^{\prime} 19^{\prime \prime}$ latitude and $74^{\circ} 21^{\prime} 09^{\prime \prime}$ longitude and at an altitude of $315 \mathrm{~m}$ above MSL. Jobat Tehsil situated at $22.42^{\circ} \mathrm{N} 74.54^{\circ}$
E. It has an average elevation of 292 meters (958 feet). Jobat is located on the banks of Dohi river. Jobat is about $184 \mathrm{~km}$ away from Indore (Fig. 1).

\section{Soil sampling and processing}

GPS based one hundred surface soil samples collected from different location of Jobat Tehsil. Approx. $1.0 \mathrm{~kg}$ of representative composite soil sample was collected from and logged into properly labeled sample bag. Then soil samples were air dried and crushed with wooden pestle and mortar and sieved through $2 \mathrm{~mm}$ sieve. These samples were used for determination of various characteristics of soil.

\section{Laboratory analysis of soil samples}

Soil $\mathrm{pH}$ was determined in a 1:2 soil: water suspension by glass electrode Beckman $\mathrm{pH}$ meter (Piper, 1950). The soil suspension used for $\mathrm{pH}$ determination was allowed to settle down and electrical conductivity (EC) of supernatant liquid was determined by using conductivity meter (Piper, 1950). The results are expressed in $\mathrm{dSm}^{-1}$ at $25^{\circ} \mathrm{C}$. Organic carbon content in soil was determined by Walkley and Black's rapid titration method. Five gram of soil sample was taken to which $10 \mathrm{ml}$ potassium dichromate $\left(\mathrm{K}_{2} \mathrm{Cr}_{2} \mathrm{O}_{7}\right)$ and $20 \mathrm{ml}$ commercial sulphuric acid $\left(\mathrm{H}_{2} \mathrm{SO}_{4}\right)$ were mixed. Available nitrogen was determined by modified alkaline permanganate method as described by Subbiah and Asija (1956), Available phosphorus was determined by using Olsen's extractant $(0.5 \mathrm{~N}$ Sodium Bicarbonate solution of $\mathrm{pH}$ 8.5) Olsen et al.(1954) and available potassium was extracted with Neutral Normal Ammonium Acetate (pH 7.0) and the content of potassium in the solution was estimated by Flame Photometer (Jackson, 1973). 


\section{Preparation of soil fertility maps}

Soil fertility maps were prepared using ArcGIS 10.5.1 employing kriging as the interpolation method.

\section{Category defined}

The categories were defined based of sample analyzed values obtained and presented in Table 1.

\section{Statistical analysis}

Variability of data was assessed using mean and standard deviation for each set of data.

\section{Results and Discussion}

\section{Soil reaction/pH}

The $\mathrm{pH}$ of soils of Jobat Tehsil range from 6.15 to 8.48 with a mean value of 7.67 standard deviation 0.56 and coefficient of variation $7.42 \%$ (Table 2). Out of 100 soil, sample $28 \%$ soil samples were neutral in $\mathrm{pH}$ and $64 \%$ samples were slightly alkaline (Table 3). The extent of spatial distribution of soil $\mathrm{pH}$ is shown in Fig. 2.

The variability Map (Fig. 2) of soil pH revealed that the maximum area falls under the category Class IV (7.5 to 8.5) followed by category III (6.5 to 7.5) and minimum area under category I (6.0 to 6.5) (Table 1). Neutral to slightly alkaline reaction might be due to the parent material, which is basic in nature with high or moderately high content of calcium and magnesium in a form that is readily released with weathering (Dudal, 1965).

\section{Electrical conductivity}

The electrical conductivity of soil water suspension (1:2) ranged between 0.08 to 0.74
$\mathrm{dSm}^{-1}$ at $25^{\circ} \mathrm{C}$ with mean value of $0.37 \mathrm{dSm}^{-1}$, It showed a considerable variation with type of topography of soils.

It is evident from the maximum area falls under the category III $(0.2-0.4)$ followed by category IV (0.4-08); Category II (0.1-0.2) and minimum area under category I $(<0.1)$ (Table 1). Most of the soil samples were normal for total soluble salt concentration. The extent of spatial distribution of soil electrical conductivity (EC) is shown in Fig. 3. The EC was existed as normal in Jobat $<1$ $\mathrm{dSm}^{-1}$ at $25^{\circ} \mathrm{C}$. Similar results were reported by Dilliwar et al., (2014) and Singh et al., (2014).

\section{Organic carbon (OC)}

The organic carbon content of the soils of Jobat Tehsil ranged from 0.20 to $0.81 \%$ with an average value of $0.43 \%$ with standard deviation $0.158 \%$ and coefficient of variation (CV) $36.45 \%$ (Table 2). Considering the soil test rating for organic carbon the soils of Jobat Tehsil fall under all the four rating classes of available OC content. In general out of 100 samples, $11 \%$ samples fall under very low status, $61 \%$ samples were categorized under low OC status, 23\% samples under medium OC status and 5\% samples were under high organic carbon status (Table 3). In this way, about $95 \%$ soil samples were low to medium in OC status.

Presence of higher concentration of organic carbon of surface samples was due to incorporation of organic matter on the upper layer of the soil, through roots and other plant residues and manures. Singh et al., (2014) and Shrivas et al., (2020) reported almost similar result. Area falls under low to medium status of organic carbon, which requires immediate attention to sustain the soil health of Jobat tehsil. The lower contents of organic carbon apparently resulted because of high 
temperature and good aeration which induced rapid rate of organic matter oxidation, while the declining trend towards to accumulation of crop residues every year, without substantial downward movement (Singh et al., 2016).

Spatial variability Map of organic carbon of the soils of Jobat Tehsilis depicted in Fig. 4. To prepare the organic carbon variability map soils were divided in to four categories (Table 1). It is evident from the Map that the maximum area falls under the category II (0.25 to 0.5$)$ followed by category III $(0.5$ $0.75)$; Category I (0.2 to 0.25$)$ and minimum area under category IV $(>0.75)$ area falls under low to Medium status of organic carbon which requires immediate attention to sustain the soil health of Jobat Tehsil.

Table.1 Category of various parameters and their range

\begin{tabular}{|c|c|c|c|c|c|c|}
\hline \multirow[t]{2}{*}{ Category } & \multicolumn{6}{|c|}{ Parameters and range } \\
\hline & $\mathbf{p H}$ & $\mathrm{EC}\left(\mathrm{dSm}^{-1}\right)$ & $\mathrm{OC}\left(\mathrm{g} \mathrm{kg}^{-1}\right)$ & $\begin{array}{c}\text { Available } \\
\left.\text { N (kg ha }{ }^{-1}\right)\end{array}$ & $\begin{array}{l}\text { Available P } \\
\quad\left(\mathrm{kg} \mathrm{ha}^{-1}\right)\end{array}$ & $\begin{array}{c}\text { Available K } \\
\qquad\left(\mathrm{kg} \mathrm{ha}^{-1}\right)\end{array}$ \\
\hline $\mathbf{I}$ & $<6.0$ & $<0.1$ & $0.20-0.25$ & $<120$ & $<5$ & $<120$ \\
\hline II & $6.0-6.5$ & $0.1-0.2$ & $0.25-0.5$ & $120-150$ & $5-10$ & $120-150$ \\
\hline III & $6.5-7.5$ & $0.2-0.4$ & $0.5-0.75$ & $150-250$ & $10-15$ & $150-250$ \\
\hline IV & $7.5-8.5$ & $0.4-0.8$ & $>0.75$ & $250-400$ & $15-20$ & $250-400$ \\
\hline $\mathbf{V}$ & - & - & - & - & $>20$ & $>400$ \\
\hline
\end{tabular}

Table.2 Minimum, maximum, mean, standard deviation and coefficient of variance values of all the samples

\begin{tabular}{|c|c|c|c|c|c|c|}
\hline Particulars & $\mathbf{p H}$ & $\mathbf{E C}\left(\mathbf{d S m}^{-\mathbf{1}}\right)$ & $\mathbf{O C}(\boldsymbol{\%})$ & $\mathbf{N}\left(\mathbf{k g ~ h a}^{-\mathbf{1}}\right)$ & $\mathbf{P}\left(\mathbf{k g ~ h a}^{\mathbf{- 1}}\right)$ & $\mathbf{K}\left(\mathbf{k g ~ h a}^{\mathbf{- 1}}\right)$ \\
\hline MIN & 6.15 & 0.08 & 0.20 & 96.00 & 0.60 & 114.46 \\
\hline MAX & 8.48 & 0.74 & 0.81 & 315.00 & 25.20 & 472.64 \\
\hline MEAN & 7.671 & 0.371 & 0.434 & 188.41 & 13.62 & 243.17 \\
\hline SD & 0.569 & 0.127 & 0.158 & 52.914 & 3.805 & 73.697 \\
\hline CV (\%) & 7.42 & 34.23 & 36.45 & 28.08 & 27.94 & 30.31 \\
\hline
\end{tabular}

Table.3 Percentage of $\mathrm{pH}, \mathrm{EC}$ and $\mathrm{OC}$ samples falls under various range

\begin{tabular}{|c|c|c|c|c|c|}
\hline Soil pH & $\begin{array}{c}\text { Samples } \\
(\mathbf{\%})\end{array}$ & $\mathbf{E C ~}\left(\mathbf{d S ~ ~ m ^ { - 1 } )}\right.$ & Samples (\%) & Organic carbon (\%) & $\begin{array}{c}\text { Samples } \\
(\boldsymbol{\%})\end{array}$ \\
\hline Strongly acid (<5.0) & - & $<0.8$ & $100 \%$ & Very Low $(<0.25)$ & $11 \%$ \\
\hline Moderately acid (5-6.0) & - & $0.8-1.6$ & - & Low $(0.25-0.50)$ & $61 \%$ \\
\hline Slightly acid (6.0-6.5) & $8 \%$ & $1.6-2.5$ & - & Medium $(0.50-0.75)$ & $23 \%$ \\
\hline Neutral (6.5-7.5) & $28 \%$ & $>2.5$ & - & High $(>0.75)$ & $5 \%$ \\
\hline Slightly alkaline (7.5-8.5) & $64 \%$ & - & - & - & - \\
\hline
\end{tabular}


Table.4 Percentage of NPK samples falls under various range/rating

\begin{tabular}{|c|c|c|c|c|c|}
\hline Available-N $\left(\mathrm{kg} \mathrm{ha}^{-1}\right)$ & $\begin{array}{l}\text { Samples } \\
(\%)\end{array}$ & $\begin{array}{l}\text { Available-P (kg } \\
\left.\text { ha }^{-1}\right)\end{array}$ & $\begin{array}{c}\text { Samples } \\
(\%)\end{array}$ & $\begin{array}{l}\text { Available-K (kg ha } \\
{ }_{1}^{-}\end{array}$ & $\begin{array}{c}\text { Samples } \\
(\%)\end{array}$ \\
\hline Low $(<250)$ & $88 \%$ & $\operatorname{Low}(<10.0)$ & $18 \%$ & Low $(<250)$ & $52 \%$ \\
\hline Medium (250-400) & $12 \%$ & Medium (10-20) & $78 \%$ & Medium (251-400) & $43 \%$ \\
\hline High $(>400)$ & - & High $(>20)$ & $4 \%$ & High $(>400)$ & $5 \%$ \\
\hline
\end{tabular}

Fig.1 Sampling point as per GPS location of Jobat Tehsil

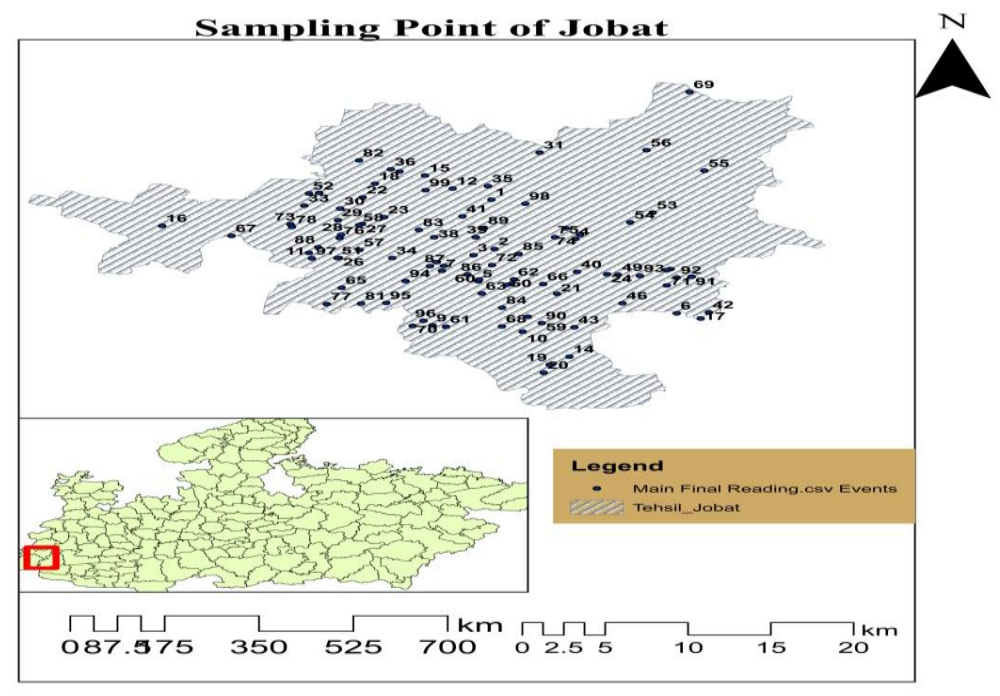

Fig.2 Spatial distribution of $\mathrm{pH}$ in the soils of Jobat Tehsil

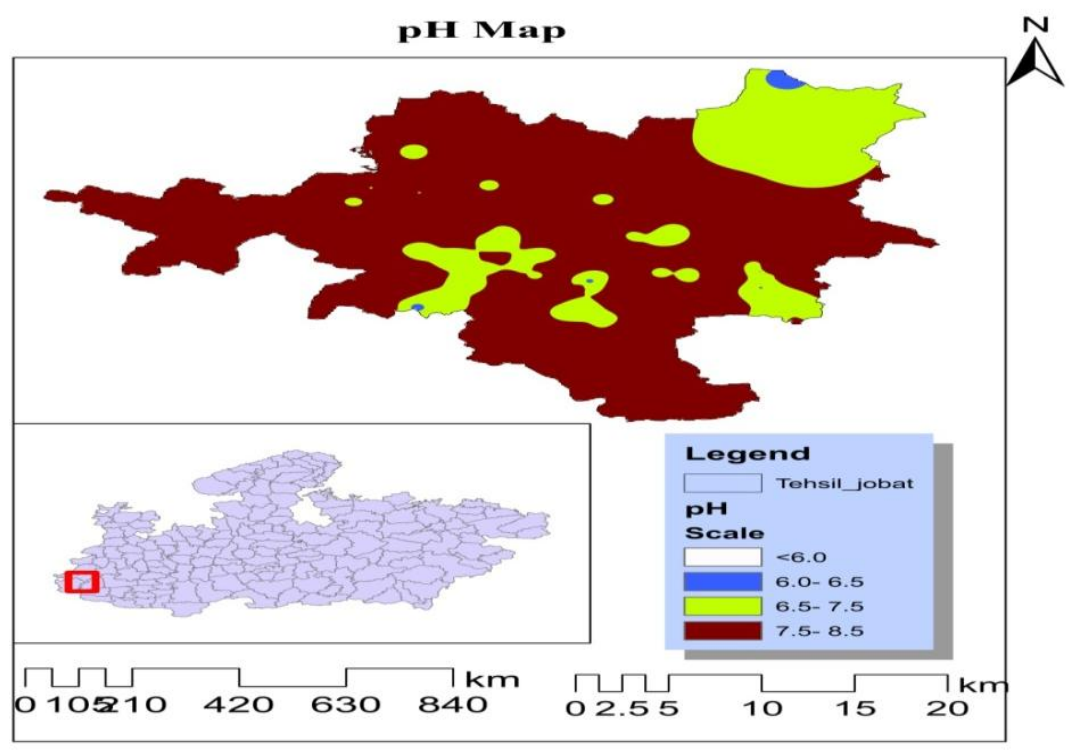


Fig.3 Spatial distribution of EC in the soils of Jobat Tehsil

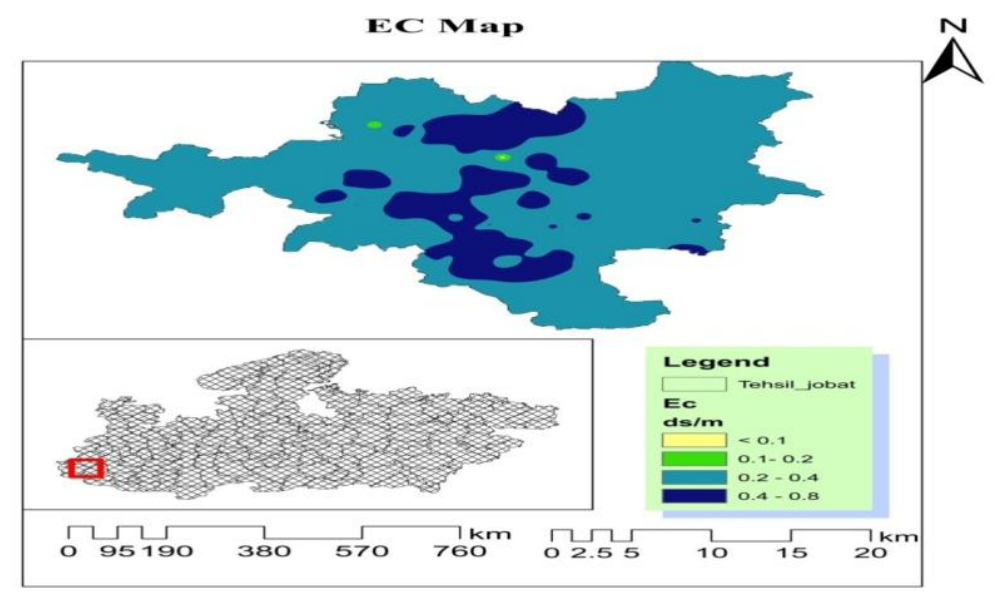

Fig.4 Spatial distribution of organic carbon in the soil of Jobat Tehsil

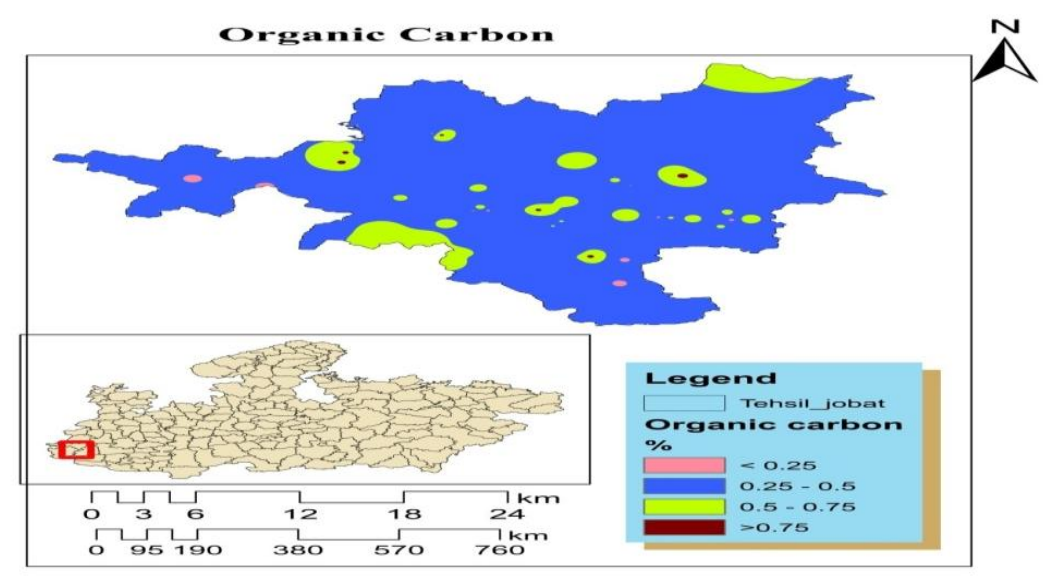

Fig.5 Spatial distribution of available $-\mathrm{N}$ in the soils of Jobat Tehsil

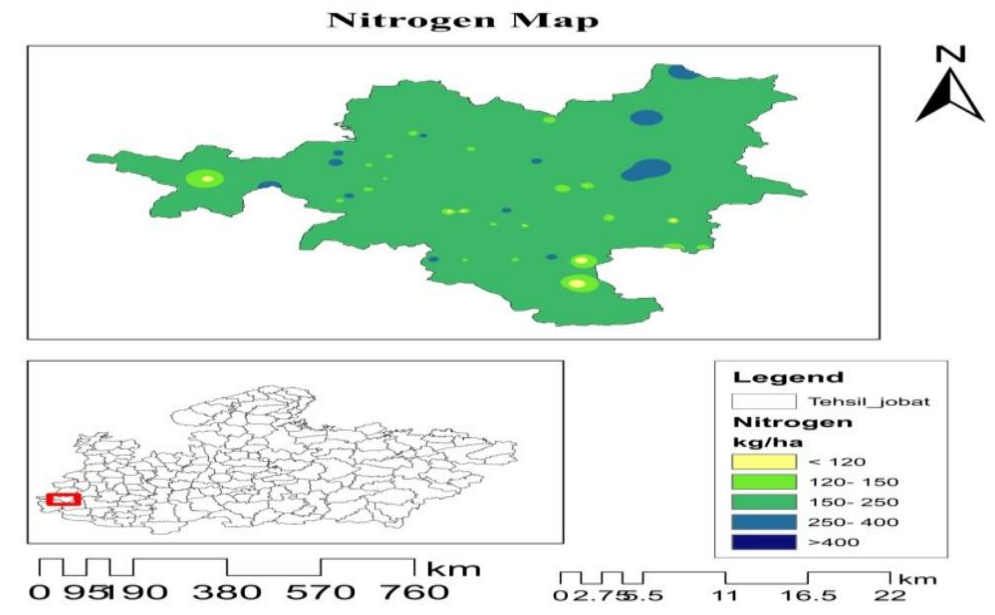


Fig.6 Spatial distribution of available-P in the soils of Jobat Tehsil

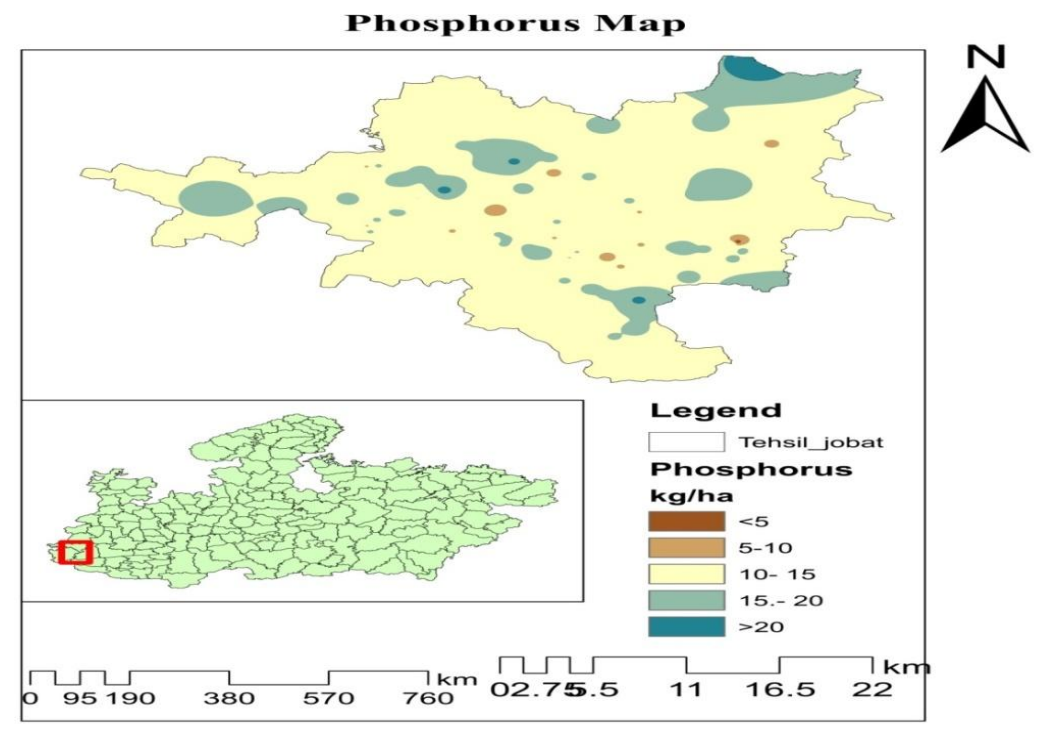

Fig.7 Distribution of available K status in the soils of Jobat Tehsil
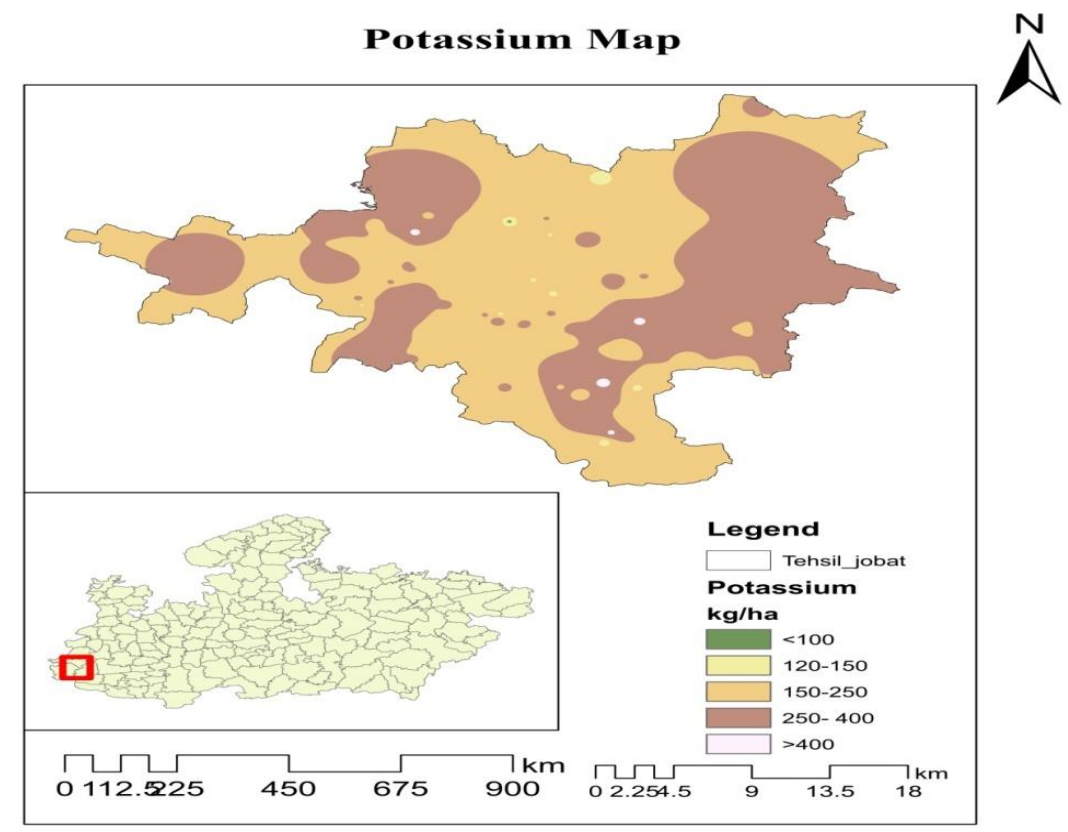

\section{Available macronutrients}

\section{Available nitrogen}

The available $\mathrm{N}$ content (Table 2) of the soils of Jobat Tehsil ranged from 96 to $315 \mathrm{~kg} \mathrm{ha}^{-1}$ with an average value of $188.41 \mathrm{~kg} \mathrm{ha}^{-1}$ with standard deviation $52.91 \mathrm{~kg} \mathrm{ha}{ }^{-1}$ and coefficient of variation (CV\%) $28.08 \%$. In general out of 100 samples $88 \%$ fall under low status and $12 \%$ samples were categorized under Medium N status (Table 4).

The soils of Jobat Tehsil fall under low to medium status $\left(<250-400 \mathrm{~kg} \mathrm{ha}^{-1}\right)$ in available $\mathrm{N}$ content. Which might be due the medium to 
low organic matter content of these soils. The reason for low content of available nitrogen might be due to the fact that $\mathrm{N}$ is lost through various mechanism like volatilization, nitrification, denitrification, microbial fixation, leaching and runoff which resulted in low amount of available $\mathrm{N}$ in soil.

The medium nitrogen status was noticed in some area may be due to application of $\mathrm{N}$ fertilizer coupled with high vegetative cover. Kumar et al., (2009) in Dumka and Lachimpur series and Ashok et al., (2006) in Auraiya district of Uttar Pradesh observed a similar trend of nutrient status in their study area soils.

It is evident from the map that the Maximum area falls under the category III (150 to 250 $\mathrm{kg} \mathrm{ha}^{-1}$ ) followed by category II (120 to 150 $\mathrm{kg} \mathrm{ha}{ }^{-1}$ ) and category IV (250-400kg ha-1). Minimum area under category I $(<120$ $\mathrm{kg} \mathrm{ha}^{-1}$ ) (Table 1). This kind of Map will help the farmers for site specific nutrient management on the basis of soil test value.

\section{Available phosphorus}

The available $\mathrm{P}$ content (Table 2) of the soils of Jobat Tehsil ranged from 0.60 to $25.20 \mathrm{~kg}$ ha-1with an average value of $13.62 \mathrm{~kg} \mathrm{ha}^{-1}$ with standard deviation $3.80 \mathrm{~kg}$ ha-1and Coefficient of Variation (CV\%) 27.94. The soils of Jobat Tehsil fall under low to medium in available $\mathrm{P}$ content. $18 \%$ samples were low $\mathrm{P}$ status, $78 \%$ samples under medium $\mathrm{P}$ status and $4 \%$ samples were high in P status.

A low to medium range of soil available $\mathrm{P}$ under study area may be mostly affected by past fertilization, $\mathrm{pH}$, organic matter content, texture various soil management and agronomic practices (Verma et al., 2005).

To prepare the $\mathrm{P}$ variability map soils were divided in to five categories (Table 2). Fig. 6 showed spatial variability Map of available-P of Jobat Tehsil. It is observed that the maximum area falls under the category III (10 to $15 \mathrm{~kg}$ ha-1) followed by category IV (15$\left.20 \mathrm{~kg} \mathrm{ha}^{-1}\right)$; category $\left(5-10 \mathrm{~kg} \mathrm{ha}^{-1}\right) ;(<20 \mathrm{~kg}$ $\left.\mathrm{ha}^{-1}\right)$ and minimum area under category III $\left(<5 \mathrm{~kg} \mathrm{ha}^{-1}\right)$ (Table 1).

\section{Available potassium}

The data in Table 2 indicated that available $\mathrm{K}$ content of the soils of Jobat Tehsil ranged from 114.46 to $472.64 \mathrm{~kg} \mathrm{ha}^{-1}$ with an average value of $243.17 \mathrm{~kg} \mathrm{ha}{ }^{-1}$ with, standard deviation $73.69 \mathrm{~kg} \mathrm{ha}^{-1}$ and coefficient of variation (CV) $30.31 \%$. The soils of Jobat Tehsil fall under low to medium status in available $\mathrm{K}$ content. In general out of 100 samples, $43 \%$ samples fall under medium status and 52\% samples were Low in K status (Table 4).

The spatial variability map of available-K of soils of Jobat Tehsil (Fig. 7). Indicated that the maximum area falls under the category III $\left(150-250 \mathrm{~kg} \mathrm{ha}^{-1}\right)$ followed by category IV (250-400 kg ha $\left.{ }^{-1}\right)$; category $\mathrm{V}\left(>400 \mathrm{~kg} \mathrm{ha}^{-1}\right)$; $\left(120-150 \mathrm{~kg} \mathrm{ha}^{-1}\right)$ and minimum area under category I ( $\left.<100 \mathrm{~kg} \mathrm{ha}^{-1}\right)$. Adequate (medium or high) available $\mathrm{K}$ in these soils may be attributed to the prevalence of potassium-rich minerals like Illite and Feldspars (Sharma et al., 2008).

In conclusion the soli of Jobat Tehsil of Alirajpur District has nutral to slightly alkaline soil reaction, normal EC, OC was found in very low to high range, however, the majority of samples falls under low range. With respect to primary nutrients majority of the of Jobat was low in available $\mathrm{N}$, medium in available $\mathrm{P}$ and also low in available $\mathrm{K}$. Based on data obtained after analysis; the maps of all parameters were prepared which will be successfully used in the future for site specific nutrient management. 


\section{Acknowledgement}

Authors expressed their deep thanks to NRDMS, Dept. of Science \& technology, GOI, New Delhi and College of Agriculture, Indore (M.P.) for providing financial assistant and all the necessary facilities for the successful conduct of present work.

\section{References}

Ashok., G., Singh R, Aggarwal S. and Kumar P. 2006. NPK status of wheat growing soils in Auraiya district of Uttar Pradesh. Int. J. Agric. Sci. 2 (1): 286287.

Dilliwar, P., Puri, G, Singh R, Amule, F.C. and Choudhary B.K. 2014. To evaluate the soil quality of Kheriseries under Jawaharlal Nehru Krishi Vishwa Vidyalaya soil of Maharajpur Farm. National conference on soil health: A key to unlock and sustain production potential September 3-4 held at Department of Soil Science and Agricultural Chemistry, College of Agriculture, JNKVV, Jabalpur (M.P.).

Dudal, R., 1965. Dark Clay Soils of Tropical and subtropical Regions. Agric. Dev. Paper 83, FAO, Rome, Italy. Pp. 161.

Havlin, H.L., Beaton , J.D. Tisdale , S.L., Nelson, W.L. 2010. Soil fertility and fertilizers- An Introduction to nutrient Management. $7^{\text {Th }}$ Edition. PHI Learing Private Limited, New Delhi India. Pp. 516.

Jackson M.L. 1973. Soil chemical analysis prentice hall of India Private Limited New Delhi.

Kumar, R., Sarkar, A.S., Singh, K.P., Agarwal, B.K. and Karmakar, S. 2009. Appraisal of available nutrients status in Santhal Paraganas region of Jharkhand. J. Indian Soc. Soil Sci. 57(3): 366-369.

Olsen, S. R., Cole, C.V., Watanabe, F.S. and
Dean, L.A. 1954. Estimation of available phosphorus in soil by extraction with sodium bicarbonate. USDA, Circ. 939.

Pawar, S., B. Singh, N.S. Thakur, A.K. Sharma, and R. Shrivas 2020. Integrated Nutrient Management - A remedy for enhancing the lives of Microbes in soil. Int. J. Curr. Microbiol. App. Sci. Special Issue (10) 11-15.

Piper, C.S. 1950. Soil and Plant analysis. Inter-Science Publication., New York.

Sharma, P.K., Sood, A., Setia, R.K., Tur, N.S., Mehra, D. and Singh, H. 2008. Mapping of macronutrients in soils of Amritsar district (Punjab) A GIS approach. J. Indian Soc. Soil Sci. 56(1): 34-41

Shrivas, R., B. Singh, N.S. Thakur, A.K. Sharma, and S. Pawar 2020. Reduced tillage and use of organics: A progressive manoeuvre towards conservation of resources and improvement in soil intrinsic properties. Int. J. Curr. Microbiol. App. Sci. Special Issue (10) 24-35.

Singh Bharat, D. Bhagat, AK, Sharma, and N. Jat 2016. Assessment of decade wise temperature trends in Malwa region. Progressive Res. An Int. J. Special-V (6) 144-149.

Singh Bharat, S. Pawar, A.K. Sharma, N.S. Thakur and R. Shrivas 2020. Effect of organics and inorganics on soil properties - A step towards nutrient management in Vertisols of Malwa Region. Int. J. Curr. Microbiol. App. Sci. Special Issue (10) 1-10.

Singh Bharat, S. Singh, A.K., Sharma, N.S. Thakur R. Shrivas and S. Pawar 2017. Study of wheat crop growth and productivity monitoring for Hoshangabad district in MP using geospatial technology. Bull. Env. Pharmacol. Life Sci. Special Issue 5 
(11) 3153-3157.

Singh, A., Adak, T., Kumar, K., Shukla, S.K. and Singh, V.K. 2014. Effect of integrated nutrient management on dehydrogenase activity, soil organic carbon and soil moisture variability in a mango orchard ecosystem. J. Animal \& Plant Sci. 24(3): 843-849.

Singh, R.P. and Mishra, S.K. 2012. Available macronutrients in the soils of Chiragaon block of district Vanarasi in relations to soil characteristics. Indian J. Sci. Res. 3(1): 97-100.

Subbiah, B.V. and Asija, G.L. 1956. A rapid procedure for the determination of available nitrogen in soils. Curr. Sci.,
25, 259-260.

Verma, V.K., Setia R.K., Sharma P.K., Singh C. and Kumar A. 2005. Pedospheric variations in distribution of DTPAextractable micronutrients in soils developed on different physiographic units in central parts of Punjab, India. Int. J. Agric. Biol. 7: 243-246.

Walkley, A., and Black, C.A. 1934. An examination of the degtjareft method for determining the soil organic matter and a proposed modification of the chromic acid titration method. Soil Sci. 37, 29-38.

\section{How to cite this article:}

Deepak Kumar Ausari, Bharat Singh and Aakash, Rahul Kumawat and Yashwant Gehlot. 2020. GIS Based Mapping of Soil Fertility Status of Tehsil Jobat, District Alirajpur, Madhya Pradesh, India. Int.J.Curr.Microbiol.App.Sci. 9(10): 60-69.

doi: https://doi.org/10.20546/ijcmas.2020.910.009 